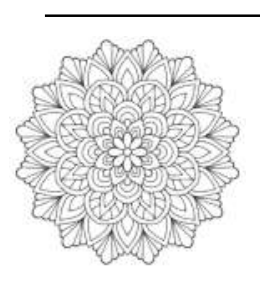

AL HIKMAH: INDONESIAN JOURNAL OF EARLY CHILDHOOD ISLAMIC

EDUCATION

ISSN (P): 2550-2200, ISSN (E): 2550-1100,

VOL. 5 (2), 2021, PP. 133 - 151

http://journal.iaialhikmahtuban.ac.id/index.php/ijecie

\title{
MANAJEMEN PENGELOLAAN MAKANAN SEHAT DAN BERGIZI DI PAUD PLUS DARUSSALAM BOJONEGORO
}

\author{
Nurul Novitasari \\ Program Studi Pendidikan Islam Anak Usia Dini, Fakultas Tarbiyah, IAI Al Hikmah Tuban \\ Nurul.novita_sari@yahoo.com \\ Abstrak
Manajemen peengelolaan makanan sehat dan bergizi di PAUD Plus Darussalam sudah berjalan \\ dengan baik. Tahapan manajemen makanan sehat di PAUD Plus Darussalam terdiri dari \\ perencanaan, pengorganisasian, pelaksanaan, dan pengawasan. Perencanaan, terdiri dari \\ perencanaan anggaran biaya dan penyusunan menu berbagai ragam menu makan siang dan kue, \\ pergantian menu makanan setiap satu bulan sekali dengan menu-menu yang paling disukai peserta \\ didik. Pengorganisasian, terdiri dari ketenagaan manajemen makanan sehat di PAUD Plus \\ Darussalam. Ketenagaan dibagi menjadi tiga kelompok, yaitu: kelompok tenaga pengelola, \\ kelompok tenaga pelaksana, dan kelompok tenaga pembantu pelaksana. Pelaksanaan, terdiri dari \\ pembelian bahan makanan, pengolahan bahan makanan, dan penyaluran makanan. Pembelian \\ bahan makanan menjadi tanggung jawab tenaga pembantu pelaksana. Pengolahan bahan makanan \\ dilaksanakan oleh tenaga pelaksana. Penyaluran makanan dilaksanakan oleh tenaga pelaksana dan \\ peserta didik sendiri sesuai dengan jadwal piket pengambilan. Pengawasan, dilakukan oleh kepala \\ sekolah dan juru masak. Jenis penelitian ini adalah penelitian lapangan (field research), dengan \\ pendekatan penelitian kualitatif. Teknik pengumpulan data menggunakan teknik observasi, \\ wawancara dan dokumentasi. analisis data menggunakan model Miles dan Huberman. Adapun \\ langkah-langkah analisis yang peneliti laksanakan antara lain: mereduksi data, penyajian data dan \\ penarikan kesimpulan
}

Kata Kunci: Manajemen Pengelolaan, makanan sehat dan bergizi

\section{Abstract}

The management of healthy and nutritious food at PAUD Plus Darussalam has been going well. The stages of healthy food management at PAUD Plus Darussalam consist of planning, organizing, implementing, and supervising. Planning, consisting of budget planning and preparation of various menus for lunch and cakes, changing the food menu once a month with the menus that students like the most. Organizing, consisting of healthy food management personnel at PAUD Plus Darussalam. The workforce is divided into three groups, namely: the management staff group, the implementing staff group, and the implementing assistant staff group. Implementation consists of purchasing food ingredients, processing food ingredients, and distributing food. The purchase of food ingredients is the responsibility of the implementing assistant. Food processing is carried out by the implementing staff. The distribution of food is carried out by the implementing staff and the students themselves according to the picket pick-up schedule. Supervision, carried out by school principals and cooks. This type of research is field research, with a qualitative research approach. Data collection techniques using observation techniques, interviews and documentation. data analysis using Miles and Huberman models. The analytical steps carried out by the researchers include: reducing data, presenting data and drawing conclusions.

Keywords: Management, healthy and nutritious food 


\section{PENDAHULUAN}

Anak usia dini adalah kelompok anak yang berada dalam proses pertumbuhan dan perkembangan unik. Anak memiliki pola pertumbuhan perkembangan (koordinasi motoric halus dan kasar), daya piker, daya cipta, bahasa dan komunikasi, yang tercakup dalam kecerdasan intelektual (IQ), kecerdasan emosional (EQ), kecerdasan spiritual (SQ), kecerdasan agama atau religious (RQ), sesuai dengan tingkat pertumbuhan dan perkembangan anak. Pertumbuhan dan perkembangan anak usia dini perlu diarahkan pada peletakan dasar-dasar yang tepat bagi pertumbuhan dan perkembangan manusia seutuhnya.(Ariyanti, 2003)

Berdasarkan Undang-Undang tentang Sistem Pendidikan Nasional dinyatakan bahwa Pendidikan anak usia dini (PAUD) adalah suatu upaya pembinaan yang dtijukan kepada anak sejak lahir sampai dengan usia enam tahun yang dilakukan melalui pemberian rangsangan Pendidikan untuk membentuk pertumbuhan dan perkembangan jasmani dan rohani agar anak memiliki kesiapan dalam memasuki Pendidikan lebih lanjut.(UU Nomor 20 Tahun 2003 Bab 1 Pasal 1 Ayat 14, 2003)

Kebutuhan dasar anak usia dini yang pertama dan paling penting adalah kebutuhan akan nutrisinya. Dewasa ini banyak sekali bermunculan PAUD berbasis fullday school, dimana anak-anak bermain dan belajar di lembaga pendidikan selama seharian penuh. Selama di lembaga PAUD tersebut, anak-anak harus tetap tercukupi kebutuhan akan nutrisinya. Sehingga lembaga PAUD fullday harus menyediakan makan siang untuk anak didiknya. Seperti halnya di PAUD Plus Darussalam Bojonegoro merupakan Lembaga PAUD yang fullday. Dimana siswa PAUD sekolah mulai pukul 07.00-12.00 WIB, dilembaga setiap hari mulai hari senin-jum'at telah disediakan snack dan makan siang. Di sekolah, makanan perlu disediakan dengan tujuan untuk mempertahankan konsentrasi dan kemampuan belajar, memberi kontribusi bagi asupan diet keseluruhan, mengajarkan tentang makanan dan nutrisi serta aspek sosial dari makanan.

Anak usia dini sedang mengalami masa pertumbuhan dan perkembangan yang pesat. Kesehatan dan gizi anak sangat mempengaruhi proses tumbuh kembang. Oleh karena itu perawatan kesehatan dan gizi sangat diperlukan untuk pengoptimalan perkembangan anak. Kondisi anak yang sempurna baik secara fisk, mental/psikis dan social (bebas dari penyakit, kelemahan dan kecacatan). 
Hasil riset kesehatan dasar (Riskesda) tahun 2018 menunjukkan 17,7\% bayi usia dibawah 5 tahun masih mengalami masalah gizi. Angka tersebut terdiri atas balita yang mengalami gizi buruk sebesar 3,9\% dan yang menderita gizi kurang sebesar 13,8\% (Kemenkes RI, 2018). Melihat data tersebut telah menemukan dari total balita Fakta yang ada bahwa status gizi anak-anak Indonesia sangat memprihatinkan masih banyak anak yang kurang gizi, mengalami efisiensi vitamin D bertubuh pendek dan kurus, serta menderita anemia. Kurang energi dan Protein (KEP) pada anak masih menjadi masalah gizi dan kesehatan masyarakat di Indonesia. Keadaan ini berpengaruh kepada masih tingginya angka kematian bayi. Menurut WHO lebih dari 50\% kematian bayi dan anak terkait dengan gizi kurang dan gizi buruk, oleh karena itu masalah gizi perlu ditangani secara cepat dan tepat.

Hasil riset kesehatan dasar mengungkapkan bahwa jumlah penderita gizi kurang/buruk dikalangan anak balita cukup tinggi, sementara jumlah anak juga meningkat. Inilah fenomena beban ganda yang kini dihadapi bangs akita. Kondisi masyarakat juga dibebani oleh persoalan anak pendek yang jumlahnya sepertiga anak balita. Masalah giri kurang adalah suatu masalah gizi yang disebabkan karena kurangnya asupan gizi baik dalam jangka waktu pendek maupun Panjang (Veria Setyawati, 2018).

Anak merupakan investasi sumber daya manusia (SDM) yang memerlukan perhatian khusus untuk kecukupan status gizinya sejak lahir, bahkan sejak dalam kandungan. Ketika masih dalam kandungan dikatakan: apa yang dimakan ibu itulah yang dimakan janin, kalau ibunya merokok maka berarti pula janinnya merokok, dan jika ibunya minum minuman keras maka janinnya juga ikut minum minuman keras. Setelah lahir, apa yang dimakan oleh bayi sejak usia dini merupakan fondasi yang penting bagi kesehatan dan kesejahteraannya di masa depan. Balita akan sehat jika sejak awal kehidupannya sudah diberi makanan sehat dan seimbang sehingga kualitas SDM yang dihasilkan optimal.(Auliana, 2011)

Zat gizi dari makanan merupakan sumber utama untuk memenuhi kebutuhan anak tumbuh kembang optimal sehingga dapat mencapai kesehatan yang paripurna, yaitu sehat fisik, sehat mental, dan sehat sosial. Oleh karena itu, slogan umum bahwa pencegahan adalah upaya terbaik dan lebih efektif-efisien dari pada pengobatan, harus benar-benar dilaksanakan untuk mencegah terjadinya masalah gizi pada anak. Hal ini pula yang menjadi tujuan utama Millennium Development Goals 
(MDGs) tahun 2015 yang dicanangkan UNICEF: tercapainya keadaan gizi dan kesehatan yang baik serta seimbang.

Menu makan anak usia dini haruslah makanan yang sehat. Makanan yang sehat adalah makanan yang mengandung gizi seimbang (Rahayu \& Munastiwi, 2018). Gizi seimbang adalah susunan makanan sehari-hari yang mengandung zat-zat gizi dalam jenis dan jumlah yang sesuai dengan kebutuhan tubuh, dengan memperhatikan prinsip keanekaragaman atau variasi makanan, aktivitas fisik, kebersihan, dan berat badan ideal (Auliana, 2011).

Setiap harinya, anak membutuhkan gizi seimbang yang terdiri dari asupan karbohidrat, lemak, protein, vitamin dan mineral. Asupan kandungan gizi tersebut dapat diperoleh dari makanan yang dikonsumsi yang berguna untuk pertumbuhan otak (intelegensia) dan pertumbuhan fisik. Untuk mengetahui status gizi dan kesehatan anak secara menyeluruh dapat dilihat mulai dari penampilan umum (berat badan dan tinggi badan), tanda-tanda fisik, motorik, fungsional, emosi dan kognisi anak. Berdasarkan pengukuran antropometri, maka anak yang sehat bertambah umur, bertambah berat, dan tinggi dikaitkan dengan kecukupan asupan makronutrien, kalsium, magnesium, fosfor, vitamin $\mathrm{D}$, yodium, dan seng.

Pelaksanaan atau penyelenggaraan makanan sehat di lembaga PAUD Plus Darussalam Bojonegoro sangatlah penting, mengingat anak usia dini sedang berada dalam masa emas pertumbuhan dan perkembangan, sehingga harus menerima asupan makanan yang sesuai untuk pertumbuhan dan perkembangnnya. Peneliti akan melaksanakan penelitian di PAUD Plus Darussalam Bojonegoro, sekolah ini dipilih karena PAUD Plus Darussalam Bojonegoro adalah lembaga PAUD yang menyediakan snack dan makan siang untuk peserta didiknya. Penyediaan makan siang di PAUD Plus Darussalam Bojonegoro dikelola sendiri oleh pihak sekolah, bukan menggunakan jasa catering, sehingga penyediaan makan siang dapat diawasi langsung oleh Kepala Sekolah beserta tim penyelenggara makanan.

Menurut Pedoman Gizi Rumah Sakit (Peraturan Menteri Kesehatan RI No 41 Tahun 2014) Manajemen makanan atau penyelenggaraan makanan merupakan serangkaian kegiatan mulai dari perencanaan menu hingga pendistribusian makanan kepada konsumen guna mencapai status gizi yang optimal. Rangkaian kegiatan yang dimaksud antara lain: perencanaan menu, perencanaan kebutuhan bahan makanan, 
perencanaan anggaran belanja, pengadaan bahan makanan, distribusi dan pencatatan, pelaporan serta evaluasi. Penyelenggaraan makanan di sekolah termasuk jenis penyelenggaraan makanan institusi yang berorientasi pelayaan (bersifat non-komersial). Penyelenggaraan makanan di sekolah sudah menjadi kebutuhan penting untuk semua warga sekolah, terutama untuk anak didik di lingkungan lembaga PAUD (TK/RA).

\section{METODE}

Jenis penelitian ini adalah penelitian lapangan (field research), dengan pendekatan penelitian kualitatif. Pendekatan kualitatif adalah prosedur penelitian yang menghasilkan data deskriptif berupa kata-kata tertulis atau lisan dari orang-orang dan perilaku yang diamati (Margono, 2009). Subjek penelitian ini adalah adalah kepala sekolah, guru, dan siswa di PAUD Plus Darussalam Bojonegoro. Teknik keabsahan data menggunakan data trainggulasi dengan sumber. Sesuai dengan pendapat Meleong yaitu triangulasi merupakan Teknik pemeriksaan keabsahan data yang memanfaatkan sesuatu yang lain. Teknik pengumpulan data menggunakan teknik observasi, wawancara dan dokumentasi. analisis data menggunakan model Miles dan Huberman. Adapun langkah-langkah analisis yang peneliti laksanakan antara lain: mereduksi data, penyajian data dan penarikan kesimpulan (Sugiono, 2011).

\section{HASIL DAN PEMBAHASAN}

Manajemen adalah proses perencanaan, pengorganisasian, pengarahan dan pengawasan terhadap suatu usaha-usaha para anggota organisasi dan penggunaan sumber-sumber daya organisasi lainnya agar mencapai tujuan organisasi yang telah ditetapkan (Wijayanto, 2012). Dalam penelitian ini menggunakan proses manajemen menurut George $\mathrm{R}$ Terry sebagai berikut: Planning, organizing, actuating, controlling. Empat fungsi tersebut dapat digambarkan sebagai suatu kegiatan yang saling berhubungan yang dilakukan oleh manajer pada umumnya.

\section{Perencanaan (Planning)}

Proses manajemen harus dimulai dengan perencanaan. Perencanaan salah satu proses yang merupakan fungsi utama dari manajemen. Ini Tindakan yang harus dilakukan dilakukan (type of work), mengapa melakukan (objective), kapan melakukannya (time), dimana melakukannya (place of location), bagaimana melakukannya (methods and prosedures), dan siapa yang melakukannya (people) (Pranama, Cipta, 2021). 


\section{Pengorganisasian (Organizing)}

Jenis rencana yang akan dilakukan menentukan pengorganisasian. Tujuannya adalah untuk menyiapkan struktur organisasi dan desain formal yang dibutuhkan, yang terdiri dari tugas masing-masing personal dalam ogranisasi, otoritas yang bertanggungjawab, jaringan komunikasi, dan skema untuk mengatur semua aspek yang diperlukan (Pranama, Cipta, 2021).

\section{Penggerakan (Actuating)}

Actuating atau penggerakan adalah usaha untuk menggerakkan atau mengarahkan seluruh anggota agar mau bekerjasama dan bekerja secara efektif untuk mencapai tujuan atau sasaran tertentu (Rahayu \& Munastiwi, 2018).

\section{Pengawasan (controlling)}

Dalam konteks manajemen, mengendalikan adalah suatu kegiatan dalam oerganisasi agar pelaksanaannya yang dilakukan sesuai dengan yang direncanakan. Fungsi control berguna untuk mendeteksi adanya kekurangan dan kesalahan sehingga dapat segera diperbaiki (Pranama, Cipta, 2021).

PAUD Plus Darussalam adalah Lembaga PAUD yang menyediakan snack dan makan siang untuk anak didiknya. Penyediaaan makan siang di PAUD Plus Darussalam dikelola oleh pihak sekolah sendiri yaitu oleh ibu kepala sekolah. Kegiatan tersebut sesuai dengan proses manajemen yang dikemukakan oleh George R. Terry, yaitu planning, organizing, actuating dan controling. Penyediaan snack dan makan siang di PAUD Plus Darussalam Bojonegoro meliputi, tim ketenagaan, perencanaan menu, pelaksanaan pembuatan makanan, pengolahan bahan makanan, dan penyaluran makanan.

\section{Planning (perencanaan)}

a. Perencanaan anggaran biaya

System pembelajaran di PAUD Plus Darussalam adalah fullday, dimana siswa mulai masuk sekolah pada pukul 07.00 dan pulang sekolah pukul 12.00 WIB karena ada kegiatan jama'ah dhuhur Bersama, sehingga semua siswa mendapatkan snack dan makan siang di sekolah.

Anggaran pembiayaan snack dan makan siang siswa diperoleh dari pembayaran SPP tiap bulan. Setiap siswa dianggarkan biayanya sebesar 8.000 perhari, jadi selama satu bulan persiswa biaya makan siang dan snack sebesar 160.000,00 (seratus enam puluh ribu). Menurut data di sekolah secara keseluruhan peserta 
didik di PAUD Plus Darussalam yang playgroup sebanyak 175 siswa, sedangkan RA sebanyak 245 siswa. Dana tersebut diberikan setiap bulan oleh bendahara sekolah. Perencanaan anggaran biaya snack dan makan siang di PAUD Plus Darussalam sepenuhnya diatur oleh bendahara sekolah melalui persetujuan kepala sekolah.

b. Penyusunan menu

Penyusunan menu snack dan makan siang di PAUD Plus Darussalam diserahkan sepenuhnya kepada tim pengelola makanan dari guru-guru sendiri dan juru masak sekolah, yaitu Ibu Supiah \& Ibu Tinah. Penyusunan menu snack dan makan siang di PAUD Plus Darussalam ditentukan oleh tim pengelola makanan dengan membuat daftar menu selama satu semester. Dalam pelaksanaanya, menu setiap satu semester selalu diganti disesuaikan dengan kesukaan anak-anak. Penyusunan menu snack makan siang di PAUD Plus Darussalam terdiri dari nasi, lauk pauk, sayuran, susu serta buah. Makanan bergizi merupakan makanan yang memenuhi kebutuhan gizi yang diperlukan oleh tubuh. Makanan yang sehat dan bergizi mengandung berbagai zat yang bermanfaat bagi tubuh. Makanan bergizi mengandung zat karbohidrat, protein, lemak, vitamin, dan mineral (Wahyuningsih, Nur, 2021).

Di dalam tubuh bayi dan anak juga membutuhkan elemen zinc untuk menstabilkan semua ikatan. Zinc pada bayi dan anak berhubungan pada pola pemberian makan, gangguan penyerapan, genetic, acrodermatitis enteropathica. Angka kecukupan zinc sehari yang dianjurkan menurut (Andriani, 2014) dapat dilihat pada tabel 1 berikut:

Tabel 1. Angka Kecukupan Zinc yang dianjurkan untuk anak-anak

\begin{tabular}{cc}
\hline Golongan umur & Angka kecukupan zinc (mg)/hari \\
\hline Anak: & \\
$0-6$ bulan & 1,3 \\
$1-11$ bulan & 7,9 \\
$1-3$ tahun & 8,3 \\
$4-6$ tahun & 10,3 \\
7-9 tahun & 11,3 \\
\hline
\end{tabular}


Makanan yang disediakan oleh pihak sekolah PAUD Plus Darussalam sudah memenuhi syarat sebagai makanan sehat. Setiap harinya menu snack dan makan siang terdiri dari makanan pokok berupa nasi putih, lauk pauk (nabati atau hewani) berupa ayam, daging, tempe, tahu, lele, bandeng, sayuran berupa sayur sop, sayur bening, sayur kari, sayur semur, buah terdiri dari pisang, jeruk, pir, apel, karena buah yang dikenalkan ke siswa adalah buah local, dan minuman pelengkap seperti susu, jus buah atau sari kedelai diberikan setiap hari jumat.

\begin{tabular}{|c|c|c|c|c|c|c|}
\hline \multicolumn{7}{|c|}{ IADWAL MENU KUE } \\
\hline PAUL & IUSSALAM B & ORO & & & & \\
\hline \multirow{2}{*}{ No } & \multirow{2}{*}{ MINGGU } & \multicolumn{5}{|c|}{ HARI } \\
\hline & & SENIN & SELASA & RABU & KAMIS & JUMAT \\
\hline 1 & 1 & Putu Ayu / Cake Mini & Pastel / Sosis Solo & $\begin{array}{l}\text { Donat Salju / } \\
\text { Roti Kukus Panda }\end{array}$ & Tahu Pentol/ & Brownis + Kolak Kacang Hijau / \\
\hline 2 & " & Roti Gulung & Pastel & Onde-onde & Risoles & Donat Salju + Susu \\
\hline 3 & III & Dadar Gulung Kelapa & Pastel & Zebra Kukus & $\begin{array}{c}\text { Tahu Fantasi campur } \\
\text { mi putih }\end{array}$ & $\begin{array}{c}\text { Kue Kukus Merah + Jus } \\
\text { Jambu/Susu }\end{array}$ \\
\hline 4 & IV & Kue Lumpur Kuning & Sosis Solo & Cantik Manis & Martabak & Pukis + Susu \\
\hline 5 & v & Pia Buah & Tahu Fantasi Mie & Nagasari & Lumpia & Cake Mini + Susu \\
\hline
\end{tabular}

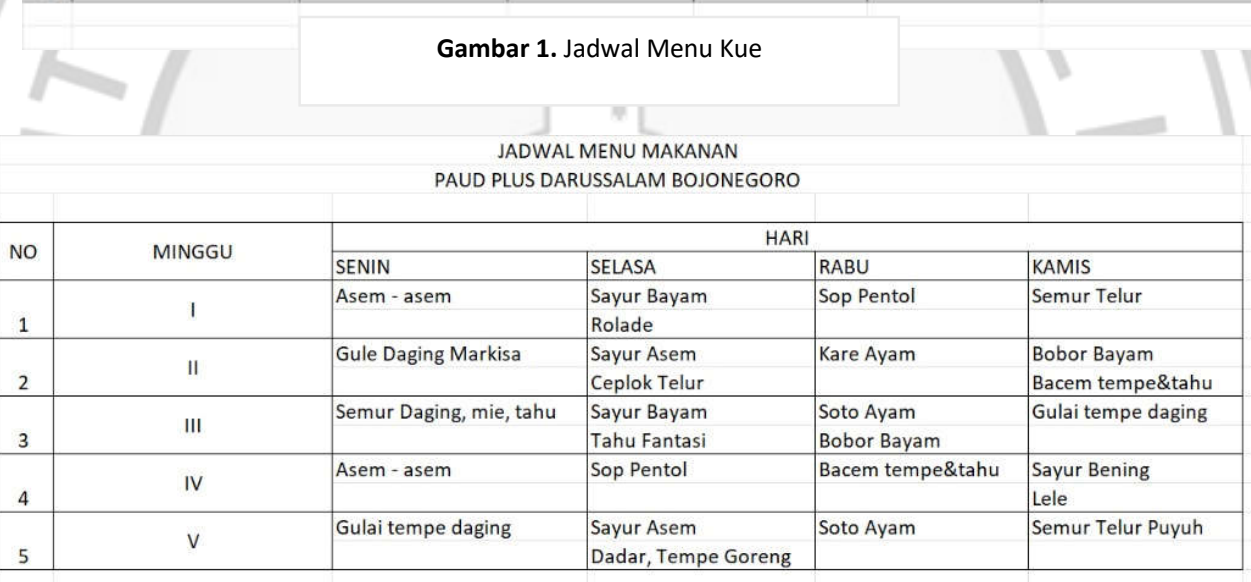

Gambar 2. Jadwal Menu Makanan

Zat-zat gizi yang seimbang tersebut bermanfaat untuk Menghasilkan tenaga yang digunakan oleh anak untuk melakukan berbagai macam kegiatan seperti belajar, berolahraga, bermain dan aktivitas lain (disebut zat tenaga). Zat makanan yang sumber tenaga utama adalah karbohidrat dan lemak. Makanan yang banyak mengandung karbohidrat adalah beras, jagung, singkong, ubi jalar, kentang, talas, gandum dan sagu. Makanan yang banyak mengandung lemak adalah daging binatang berkaki empat, unggas, ikan, mentega, keju. Makanan yang mengandung protein adalah putih telur, gandum, keju, yogurt, susu, ikan tuna, udang. Makanan yang banyak 27 mengandung vitamin (A) antara lain yaitu ubi jalar, wortel, bayam, kubis, buah blewah, pisang, paprika. Vitamin (B) antara lain yaitu 
daging ikan, seafood, telur dan produk susu. Vitamin (C) antara lain yaitu papaya, jeruk, stawbery, jambu biji, paprika, brokoli, dan sayuran berdaun hijau gelap. Vitamin (D) antara lain yaitu ikan salmon, ikan lele, susu, dan jamur. Vitamin (E) antara lain yaitu biji bunga matahari, almond, bayam, paprika. Vitamin (K) antara lain yaitu sawi, kol, bayam, brokoli (Nurjannah, 2019).

Gizi seimbang adalah susunan makanan sehari-hari yang mengandung zat-zat gizi dalam jenis dan jumlah yang sesuai dengan kebutuhan tubuh, dengan memperhatikan prinsip keanekaragaman atau variasi makanan, aktivitas fisik, kebersihan, dan berat badan ideal. Gizi seimbang di Indonesia divisualisasikan dalam bentuk tumpeng gizi seimbang (TGS) yang sesuai dengan budaya Indonesia. TGS dirancang untuk membantu setiap orang memilih makanan dengan jenis dan jumlah yang tepat sesuai dengan berbagai kebutuhan menurut usia (bayi, balita, remaja, dewasa dan usia lanjut), dan sesuai keadaan kesehatan (hamil, menyusui, aktivitas fisik, sakit).

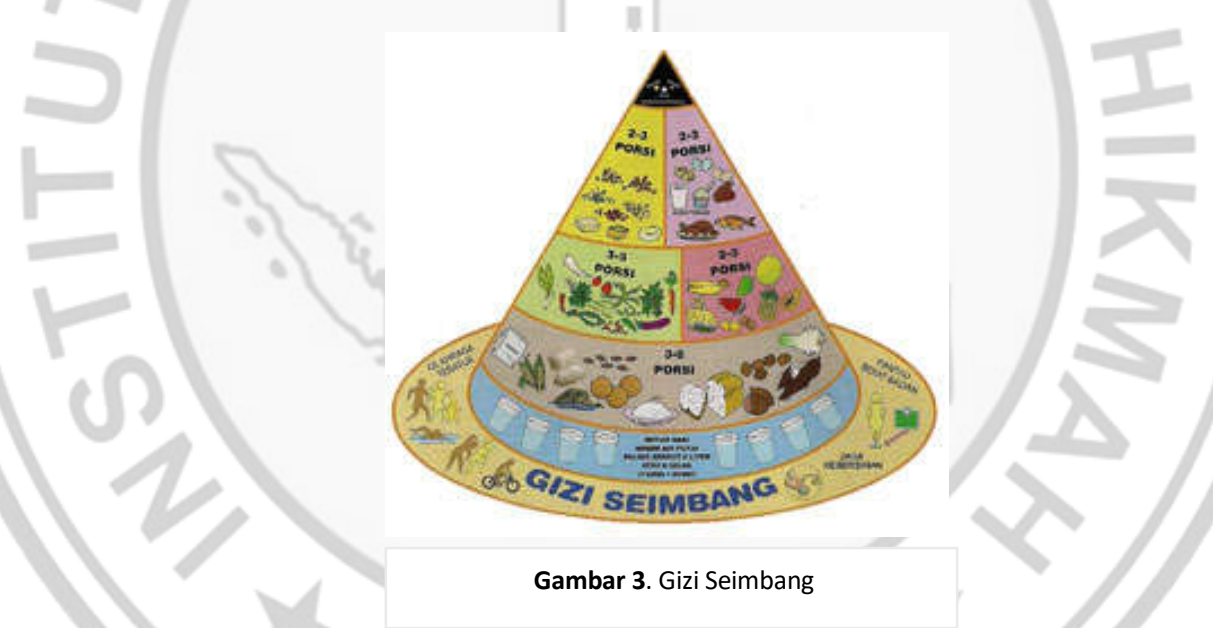

TGS terdiri dari beberapa potongan tumpeng, yaitu (Auliana, 2011):

1. 1 potongan besar: golongan makanan karbohidrat,

2. 2 potongan sedang dan 2 potongan kecil yang merupakan golongan sayuran dan buah,

3. 2 potongan kecil diatasnya yang merupakan golongan protein hewani dan nabati,

4. 1 potongan terkecil di puncak yaitu gula, garam, dan minyak yang dikonsumsi seperlunya. 
5. Potongan TGS juga dilapisi dengan air putih yang idealnya dikonsumsi 2 liter atau 8 gelas sehari.

6. Luasnya potongan TGS ini menunjukkan porsi konsumsi setiap orang per hari. Karbohidrat dikonsumsi 3 - 8 porsi, sayuran 3 - 5 porsi sedikit lebih besar dari buah, buah 2-3 porsi, serta protein hewani dan nabati 2 - 3 porsi.

7. Konsumsi ini dibagi untuk makan pagi, siang, dan malam. Kombinasi makanan per harinya perlu dilakukan.

8. Dibagian bawah TGS terdapat prinsip gizi seimbang yang lain, yaitu: pola hidup aktif dengan berolahraga, menjaga kebersihan dan pantau berat badan.

\section{Organizing (pengorganisasian)}

Ketenagaan pada penyelenggaraan makanan sehat dan bergizi di PAUD Plus Darussalam dibagi menjadi 3 kelompok. Pertama, kelompok tenaga pengelola adalah kepala sekolah dan beberapa guru lainnya sebagai tim. Tenaga pengelola bertanggungjawab atau penyusunan menu makan siang, menu snack, standarisasi kualitas gizi makanan, dan cita rasa makanan yang dihasilkan. Efisiensi dan efektifitas penggunaan dana juga menjadi tanggungjawab pengelola. Kedua, kelompok tenaga pelaksana, yang dimaksud tenaga pelaksana adalah juru masak di PAUD Plus Darussalam adalah ibu Supiah dan Ibu Tinah, dan ada ibu Atin dan Ibu Elfi bagian membagikan makanan yang sudah matang kepada anak-anak.

Ketiga, kelompok tenaga pembantu pelaksana, yang dimaksud tenaga pembantu pelaksana adalah tenaga yang terlibat dalam penyelenggaraan makanan di PAUD Plus Darussalam. Mas Feri adalah tenaga pembantu pelaksana penyelenggara di PAUD Plus Darussalam. Mas Feri bertugas penyaluran makanan kepada anak-anak didik, jam 09.00 snack sudah siap diantar ke sekolah dan jam 10.00 makan siang sudah siap di antar ke sekolah maka Mas Feri kemudian membagikan snack dan makan siang ke dapur sekolah, kemudian anak-anak mengambil makanannya sesuai dengan piket yang sudah dijadwalkan oleh guru kelasnya. 


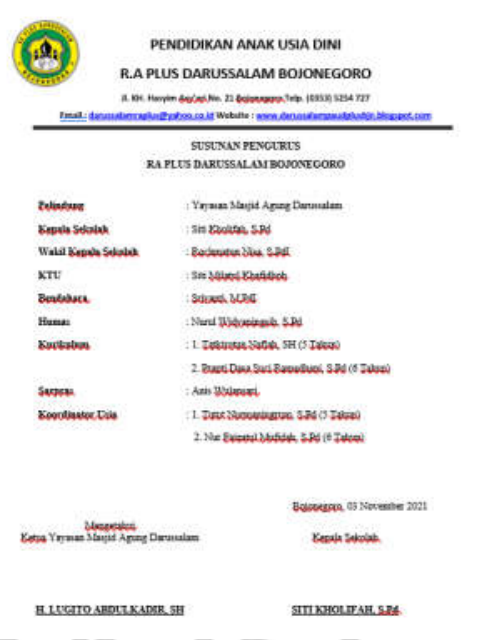

Gambar 4. Struktur Pengurus TIM Pengelola Makanan

3. Actuating (pelaksanaan)

a. Bahan makanan

Bahan makanan menjadi tanggung jawab juru masak dengan ibu kepala sekolah yang menjadi tempat pengelolaan makanan. Bahan-bahan makanan seperti beras disuplay oleh salah satu wali murid PAUD Plus Darussalam, untuk bumbunya seperti penyedap, garam, kecap dll dibeli dikoperasi Halawa, halawa adalah koperasi yang dikelola lembaga PAUD Plus Darussalam. Sedangkan sayuran langsung mengambil di greenhouse dalam keadaan segar, karena PAUD Plus Darussalam mempunyai greenhouse yang terdiri dari seledri, sawi hijau, kangkung, bayam dll. Kemudian untuk ikan seperti ayam atau sapi lembaga PAUD Plus Darussalam melakukan penyembelihan sendiri karena lebih steril dan higenis.

Sebelum melakukan pengolahan bahan makanan juru masak diberikan pembekalan terlebih dahulu oleh ibu kepala sekolah bagaimana takaran tiap komposisi yang digunakan untuk memasak maupun membuat snack. Juru masak tidak menempuh Pendidikan formal tentang tata boga, tetapi beliau sudah terbiasa memasak dan mempunyai pengalaman menjadi juru masak.

Pengolahan yang sesuai dengan standar makan akan menghasilkan anak yang sehat baik secara fisik, mental/psikis dan social (bebas dari penyakit, kelemahan dan kecacatan). Ciri-ciri anak sehat menurut (Andriani, 2014) sebagai berikut: 
Tabel 2. Ciri-ciri anak sehat

\section{Sehat secara fisik}

1. Sesuai pertumbuhan. standar badan dan tinggi badan normal

2. Kemampuan bertambah sesuai usia

3. Jarang sakit

4. Aktif/gesit gembira

5. Mata bersih dan bersinar

6. Nafsu makan baik

7. Bibir dan lidah tampak segar

8. Pernapasan tidak berbau

9. Kulit dan rambut tampak bersih dan tidak kering

\section{Sehat secara mental atau Sehat secara sosial} psikis

1. Perkembangan dengan sesuai 1. ceria tahap perkembangannya

2. Jiwa berkembang secara wajar

3. Pikiran bertambah cerdas

4. Perasaan bertambah peka

Gizi yang seimbang bukan saja untuk pertumbuhan dan perkembangan anak itu sendiri tetapi juga sangat berguna untuk meningkatkan daya tahan tubuh, daya ingat dan meningkatkan kecerdasan anak. Makin baik gizi dari makanan yang dikonsumsi oleh anak, maka akan semakin baik pula perkembangan fisik, sejalan dengan semakin baik perkembangan-perkembangan fisik anak, akan meningkatkan daya tahan tubuh anak serta meningkatkan kecerdasan. Ketika daya tahan tubuh anak semakin meningkat, anak tidak akan mudah terserang penyakit dan perkembangan anak akan semakin optimal(Widjaya, 2003) .

Makanan yang dikonsumsi oleh anak harus mengandung zat-zat gizi yang dibutuhkan oleh tubuh. Zat-zat gizi yang dibutuhkan oleh tubuh itu yaitu karbohidrat, lemak, protein, vitamin, mineral dan air. Kebiasaan dan kesukaan anak terhadap makanan mulai dibentuk sejak kecil. Anak diperkenalkan dengan berbagai jenis makanan mulai sejak usia dini. Anak-anak dibiasakan mengkonsumsi makanan yang sehat dan mengandung gizi yang seimbang dan variatif. Aneka bahan makanan yang diberikan secara bertahap dapat merangsang alat pencernaan untuk memproduksi enzim-enzim yang diperlukan (Uripi, 2004) 
b. Penyaluran makanan

Setelah semua makanan telah selesai dimasak dan snack sudah jadi, penyaluran atau pendistribusian makanan dan snack dilakukan oleh mas feri tepat pukul 07.00 sudah tiba di sekolah kemudian siswa memakannya pada pukul 09.00. sedangkan untuk makan siang pendistribusiannya pukul 09.00 siswa makan siang pada pukul 12.00. Penataan dibagikan oleh Ibu Atin dan Mas Feri sesuai dengan kelas masingmasing, kemudian diletakkan di dapur sekolah terlebih dahulu. Penataan makanan dilakukan sedemikian rupa sehingga siswa-siswi dapat mengambil makanan dengan mudah dan tertib. Pengambilan makanan anak-anak yang mendapatkan piket mengambil makan siang ke dapur sekolah yang berada di lantai satu dan menyiapkan peralatan makan yang terdapat dietalase kelas. Selama anak-anak mengambil makanan juru masak melakukan pengawasan terhadap anak-anak. Sebelum anak-anak mulai makan ada pembelajaran terlebih dahulu oleh guru kelas seperti bagaimana cara mengambil nasi dan lauk sendiri dan manfaat makan sayuran.

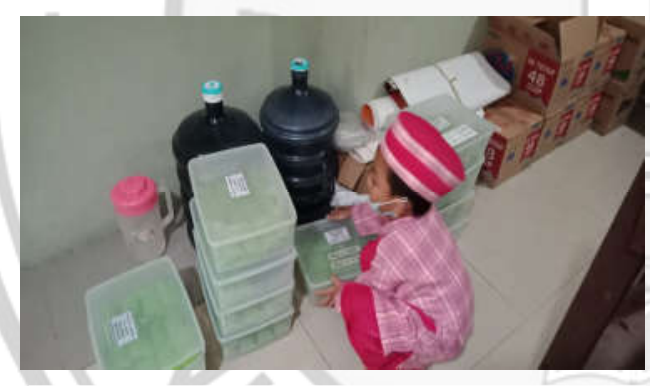

Gambar 5. Siswa piket mengambil snack

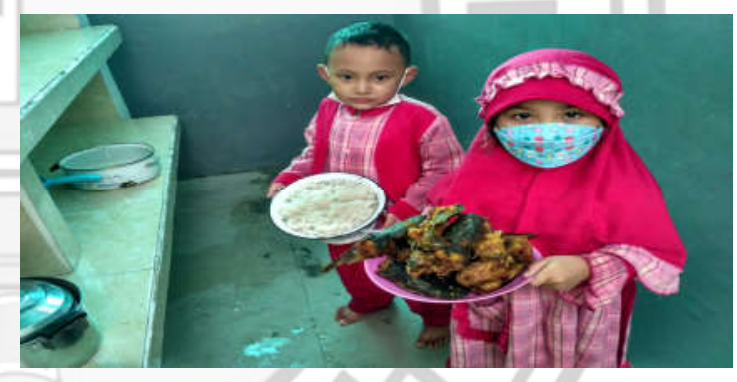

Gambar 6. Siswa piket mengambil makan siang

PAUD Plus Darussalam menyediakan menu makanan sehat dan bergizi, sehingga setiap hari selalu disediakan sayuran berkuah untuk anak makan siang. Setiap hari memakan sayur, anak didik perlahan-lahan mulai menyukai sayuran. Banyak anak yang awalnya tidak suka makan sayur. Anak-anak tidak suka memakan sayur karena rasanya yang pahit dan kebanyakan orang tua selalu memberikan lauk yang instan seperti sosis dan nuget. Peserta didik di PAUD Plus Darussalam juga dapat mengenal macam-macam sayur secara langsung, mereka dapat menyebutkan dengan jelas berbagai macam sayur yang sering dikonsumsi. 
Adanya manajemen makanan sehat dan bergizi disekolah dapat membantu guru dan orang tua menanamkan budaya makan makanan sehat dan bergizi.

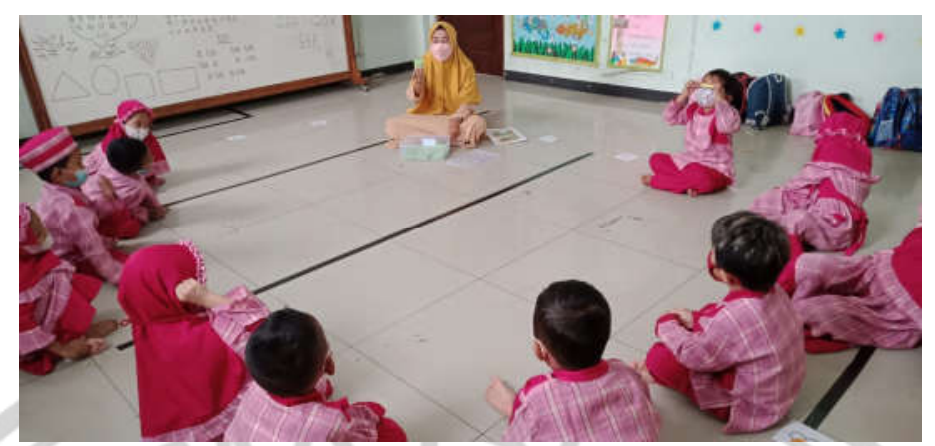

Gambar 7. Guru memberikan edukasi kepada peserta

didik terlebih dahulu tentang manfaat makan

Berdasarkan Jurnal (Setyodi, 2017) minat anak terhadap makanan perlu dilakukan pembiasaan yaitu mengkonsumsi sayur dan buah, melalui kebiasaan anak dalam mengkonsumis sayur dan buah, di butuhkan peran orangtua dalam memotivasi anak agar mengkonsumsi sayur, termasuk mengenalkan jenis, manfaat, kandungan, serta akibat kurang mengkonsumis sayur.

Suherti Yuliarti mengatakan minat anak tehadap makanan yaitu perlu Adanya pengenalan atau mengenalkan tentang makanan-makanan yang bergizi, agar anak mengetahui manfaat dari makanan tersebut.

\section{Controlling (pengawasan)}

Pengawasan dilakukan oleh ibu kepala sekolah dan tim pengelola makanan. Kepala sekolah melakukan pengawasan terhadap berbagai macam menu makanan yang telah di rancang. Sedangkan tim pengelola makanan Ibu Atin dan Ibu Alfi melakukan pengawasan terhadap pelaksanaan makan siang dan pembagian snack. Kegiatan pengawasan menu makan siang dan snack meliputi pengecekan menu makan, pemantauan pengolahan makanan, dan pencicipan makanan untuk memastikan makanan aman disajikan kepada peserta didik. Guru kelas masing-masing melakukan pengawasan ketika peserta didik sedang makan siang. Pengawasan berupa ketertiban peserta didik selama makan siang berlangsung, memastikan peserta didik makan dengan baik, memastikan peserta didik bisa mandiri mengambil sendiri, memastikan peserta didik bisa tertib dan antri untuk mengambil snack sesuai nomor utur dengan 
bergiliran, memastikan peserta didik menghabiskan makanan yang telah diambil, dan memastikan peserta didik meletakkan alat yang telah digunakan dengan rapi.

Peserta didik di PAUD Plus Darussalam dibiasakan untuk tertib, mulai dari antri mengambil makan siang, memakan makanan, sampai meletakkan alat-alat makan yang telah digunakan ditempat nampan piring kotor. Mereka berbaris dengan tertib ketika mengambil makan siang. Setelah mengambil makan siang, peserta didik duduk dengan tertib. Selama menghabiskan makan siang, peserta didik sangat tertib dan tidak menggangu teman-teman yang lain.

Makanan yang telah diambil harus dihabiskan, sehingga anak-anak akan mengambil makanan secukupnya. Setelah selesai makan, peralatan yang digunakan langsung diletakkan dan ditumpuk di nampan peralatan makan. Dengan terlaksananya manajemen makanan sehat dan bergizi di PAUD Plus Darussalam budaya tertib dapat ditanamkan kepada anak-anak sejak dini. Penanaman budaya tertib dapat dilakukan ketika anak mengambil makan siang. Anak mengambil makan siang secara bergantian dengan duduk yang rapi tanpa menyerobot antrian. Selanjutnya penanaman budaya tertib dapat dilakukan ketika anak memakan makanan. Anak memakan makanan dengan tertib, tidak mengganggu teman, tidak berbicara ketika makan, dan duduk dengan tertin, rapi serta sopan. Penanaman budaya tertib juga dapat dilakukan ketika anak mengembalikan peralatan makan yang telah digunakan ke tempat pencucian. Anak-anak mengembalikan peralatan makan dengan tertib tanpa menganggu teman-teman yang lain.

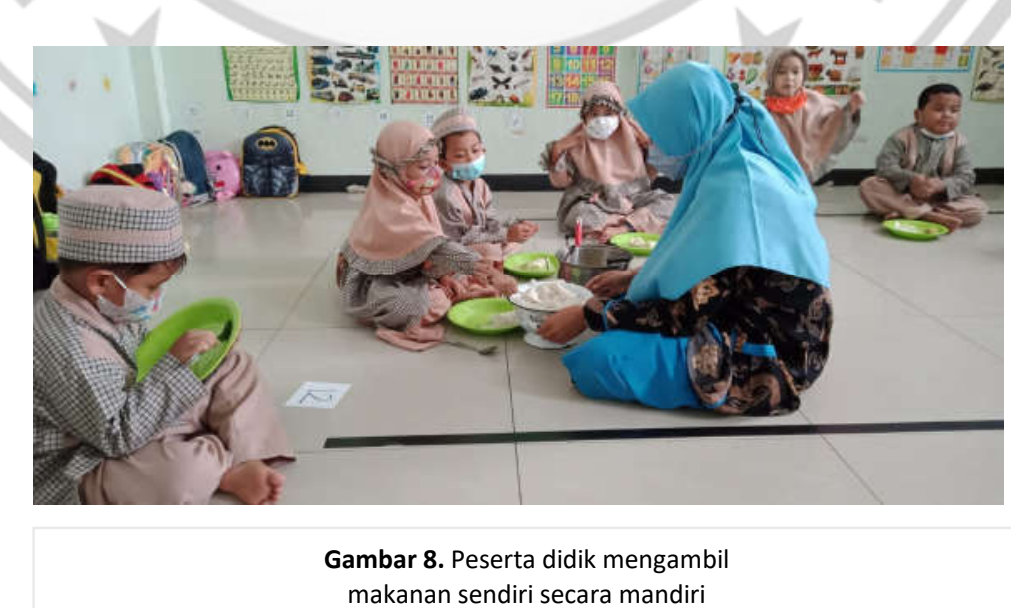


Peralatan makan yang digunakan untuk makan seperti piring, mangkok dan gelas terbuat dari plastik dengan standart seperti Tupperware agar tidak mudah pecah dan mudah dibawa dan untuk mempermudah anak ketika makan. Piring yang digunakan tidak mengandung BPA yang bisa membahayakan anak. Sedangkan sendok dan garpu berbahan aluminium yang ringan. Peralatan yang digunakan anak untuk makan sangat aman karena makanan yang dihidangkan suhunya sudah tidak terlalu panas dan aman untuk anak.

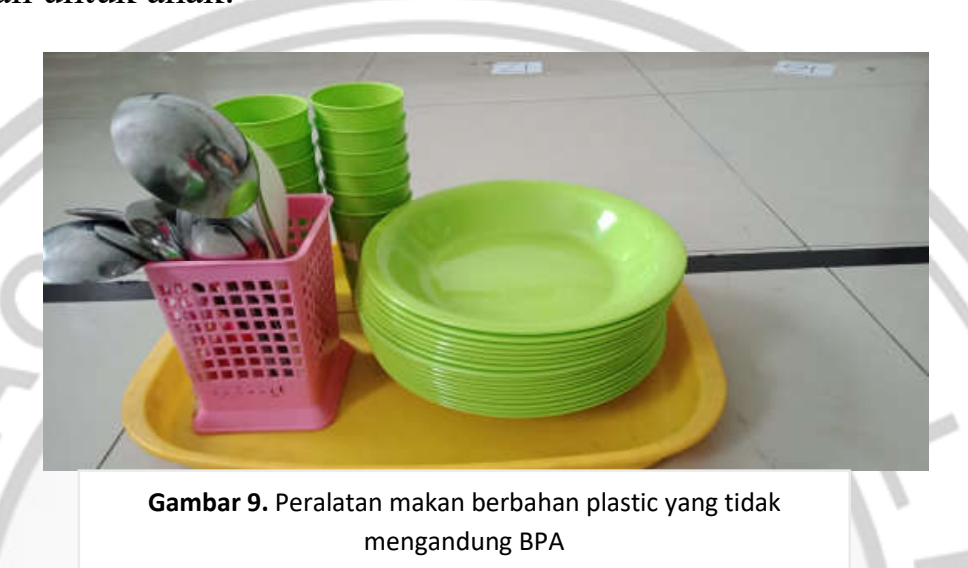

Kepandaian seorang anak ditentukan oleh perkembangan sistem saraf dan otak. Sistem saraf terdiri atas bermilyar-milyar sel yang mendeteksi informasi dari dalam dan dari luar tubuh seorang anak. Sistem saraf dan otak baru berangsur-angsur sempurna sejalan dengan usia dan tergantung pada kualitas dan kuantitas gizi yang diberikan kepada anak.24 Manfaat yang dapat diperoleh dari makanan bergizi pada anak adalah: Dapat menentukan perkembangan otak dan kecerdasan pada anak. Untuk sistem imunitas atau kekebalan pada anak sehingga anak tidak mudah terserang penyakit, tidak mudah terserang infeksi terutama diare atau cacingan. Sebagai sumber tenaga bagi anak. Untuk memberi bahan untuk membangun atau memelihara jaringan-jaringan tubuh dan pengatur pekerjaan jaringan tubuh yang terdiri dari vitamin, mineral dan air (Proverawati, 2011).

Untuk mempercepat proses pertumbuhan, gizi yang seimbang sangat berpengaruh dalam membantu proses pertumbuhan anak kearah yang lebih optimal. Untuk menunjang kecerdasan berfikir dan pertumbuhan otak, jika gizi yang diperlukan otak tidak terpenuhi, maka perkembangan otak akan terlambat, dan hal tersebut secara otomatis akan berakibat pada lemahnya tingkat kecerdasan pada anak. Untuk memperoleh energi guna melakukan kegiatan sehari-hari (Widjaya, 2003). Mengatur metabolisme dan mengatur berbagai keseimbangan air, mineral dan cairan tubuh yang lain. 


\section{PENUTUP}

\section{Simpulan}

Manajemen makanan sehat di PAUD Plus Darussalam sudah berjalan dengan baik. Tahapan manajemen makanan sehat di PAUD Plus Darussalam terdiri dari perencanaan, pengorganisasian, pelaksanaan, dan pengawasan. Perencanaan, terdiri dari perencanaan anggaran biaya bahwa setiap siswa setiap bulan anggaran biaya sebesar Rp. 160.000, 00 (serratus enam puluh ribu) dan penyusunan menu berbagai ragam menu makan siang dan kue, pergantian menu makanan setiap 1 bulan sekali dengan menu-menu yang paling disukai peserta didik. Pengorganisasian, terdiri dari ketenagaan manajemen makanan sehat di PAUD Plus Darussalam. Ketenagaan dibagi menjadi tiga kelompok, yaitu: kelompok tenaga pengelola, kelompok tenaga pelaksana, dan kelompok tenaga pembantu pelaksana. Pelaksanaan, terdiri dari pembelian bahan makanan seperti bumbu-bumbu makanan di kantin HALAWA, sedangkan ikan menyembelih sendiri, sayur-sayuran memetik sendiri di greenhouse milik sekolah, pengolahan bahan makanan, dan penyaluran makanan. Pembelian bahan makanan menjadi tanggung jawab tenaga pembantu pelaksana. Pengolahan bahan makanan dilaksanakan oleh tenaga pelaksana tetapi tetap pada pengawasan oleh tim pengelola makanan lembaga. Penyaluran makanan dilaksanakan oleh tenaga pelaksana dan peserta didik sendiri sesuai dengan jadwal piket pengambilan. Pengawasan, dilakukan oleh kepala sekolah dan juru masak.

\section{Saran}

Kekurangan manajemen makanan sehat di PAUD Plus Darussalam antara lain: menu makan kurang bervariasi dan tidak ada ahli gizi. Menu yang dibuat kurang bervariasi. Hal ini menyebabkan anak bosan dan menurun nafsu makannya. Dalam penyusunan menu makan siang belum melibatkan ahli gizi. Juru masak merencanakan menu makan siang berdasarkan pedoman "gizi seimbang". Jadi juru masak dianjurkan memiliki kualifikasi lulusan tata boga dan saat menyusunan menu makan dan snack dapat melibatkan ahli gizi.

\section{DAFTAR PUSTAKA}

Andriani, M. dan B. W. (2014). Gizi \& Kesehatan Balita: Peranan Mikro Zinc Pada

Pertumbuhan Balita. Kencana Prenadamedia Grup.

https://www.google.co.id/books/edition/Gizi_Kesehatan_Balita_Peranan_Mikro_Zinc/m fpDDwAAQBAJ?hl=en\&gbpv=1\&dq=Buku+Gizi\&printsec=frontcover 
Ariyanti, T. (2003). Pentingnya Pendidikan Anak Usia Dini Bagi Tumbuh Kembang Anak.

Auliana, R. (2011). Gizi Seimbang Dan Makanan Sehat Untuk Anak Usia Dini. Journal of Nutrition and Food Research, 2(1), 1-12.

http://staff.uny.ac.id/sites/default/files/pengabdian/rizqie-auliana-dra-mkes/giziseimbang-dan-makanan-sehat-untuk-anak-usia-dini.pdf

Kemenkes RI. (2018). Hasil Riset Kesehatan Dasar Tahun 2018. Kementrian Kesehatan RI, 53(9), 1689-1699.

Margono. (2009). Metodologi Penelitian Pendidikan. Rineka Cipta.

Nurjannah. (2019). Meningkatkan Minat Anak dalam Makanan Bergizi Melalui Coocing Class Anak Usia 5-6 Tahun di TK Budi Luhur Kabupaten Lampung Timur. Universitas Islam Negeri Raden Intan Lampung.

Peraturan menteri kesehatan RI No 41 Tahun 2014. (n.d.).

Pranama, Cipta, dkk. (2021). Dasar Ilmu Manajemen. CV. Media Sains Indonesia.

Proverawati, A. (2011). Imu Gizi Keperawatan Dan Gizi Kesehatan. Nuha Medika.

Rahayu, N., \& Munastiwi, E. (2018). Manajemen Makanan Sehat di PAUD. Golden Age: Jurnal Ilmiah Tumbuh Kembang Anak Usia Dini, 3(2), 65-80. https://doi.org/10.14421/jga.2018.32-01

Setyodi. (2017). Jurnal Ilmu Keperawatan. Fakultas Kedokteran Ilmu Brawijaya.

Sugiono. (2011). Metode Penelitian Kuantitatif, Kualitatif dan R\&D. Alfabeta.

Uripi, V. (2004). Menu Sehat Untuk Balita. PT Puspa Sawara.

UU Nomor 20 Tahun 2003 Bab 1 Pasal 1 Ayat 14. (2003). Visimedia.

Veria Setyawati, V. A. dan E. H. (2018). Dasar Ilmu Gizi Kesehatan Masyarakat (1st ed.). Deepublish. https://www.google.co.id/books/edition/Buku_Ajar_Dasar_Ilmu_Gizi_Kesehatan_Masy /YACDDwAAQBAJ?hl=en\&gbpv=1\&dq=buku+gizi + seimbang + pdf $\&$ printsec $=$ frontco ver 
Wahyuningsih, Nur, dkk. (2021). MAKANAN SEHAT DAN BERGIZI BAGI TUBUH. KMedia.

https://www.google.co.id/books/edition/MAKANAN_SEHAT_DAN_BERGIZI_BAGI _TUBUH/U1Y5EAAAQBAJ?hl=id\&gbpv=1

Widjaya. (2003). Gizi Tepat Untuk Perkembangan Otak Dan Kesehatan Balita. PT Kawan Pustaka.

Wijayanto, D. (2012). Pengantar Manajemen. PT Gramedia.

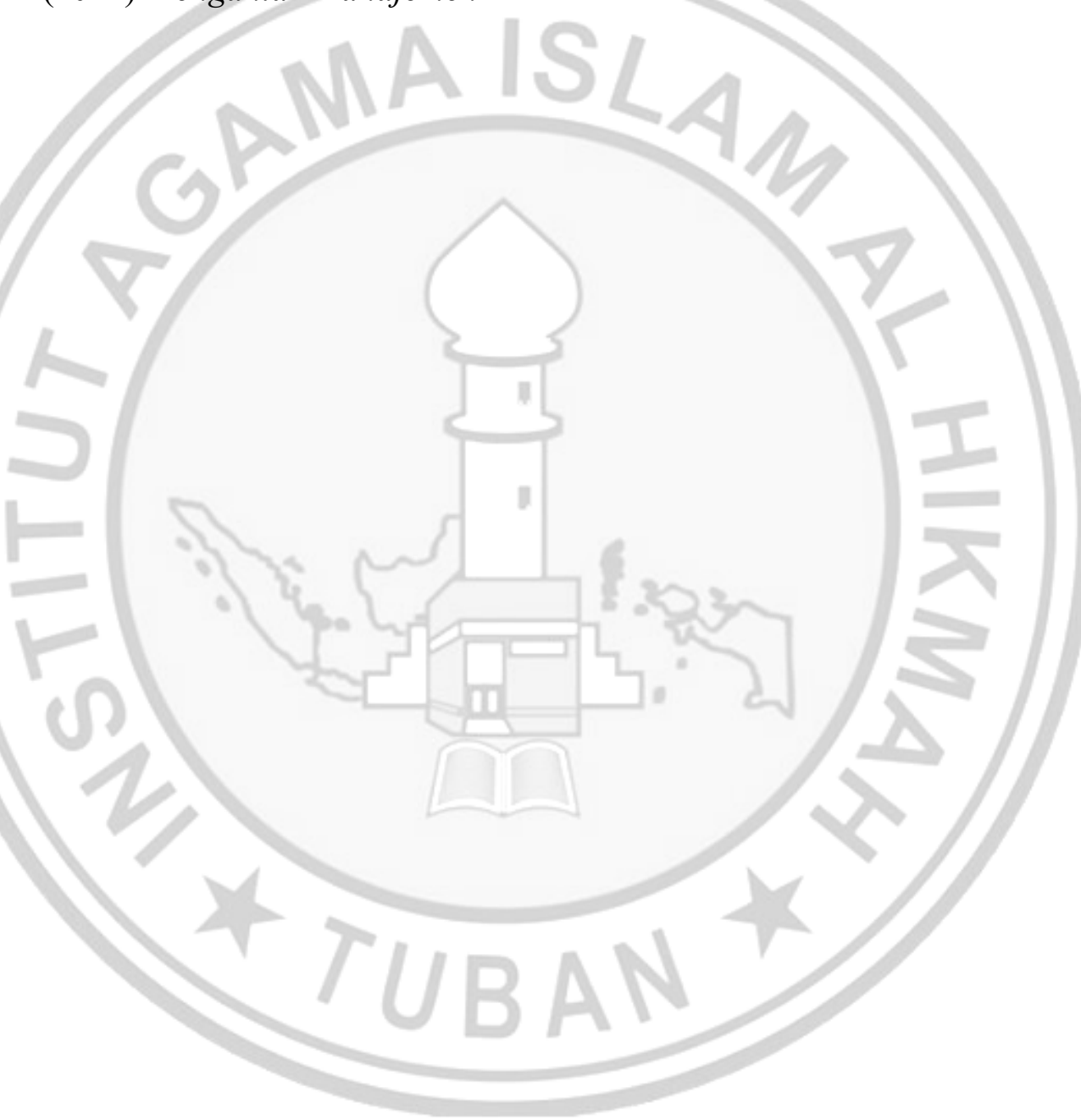

